\title{
Synthesis and Anti-Staphylococcal Activity of 2,4-Disubstituted Diphenylamines
}

\author{
Ramandeep K. Mehton, ${ }^{a}$ Vineet Meshram, ${ }^{b}$ Sanjai Saxena ${ }^{b}$ and Manmohan Chhibber ${ }^{*, a}$ \\ ${ }^{a}$ School of Chemistry and Biochemistry and ${ }^{b}$ Department of Biotechnology, Thapar University, 147004 Patiala, India
}

\begin{abstract}
Infections caused by Staphylococcus aureus are ubiquitous and life threatening. Evolution of resistant strains has necessitated the need to continuously discover new drugs to combat such organisms. Diphenyl ethers, such as triclosan, have recently shown potential as antibacterial agents. In this study, a series of diphenyl amines were synthesized and evaluated for in vitro antibacterial activity against Gram-positive (Staphylococcus aureus, Bacillus subtilis, Staphylococcus epidermidis) and Gram-negative (Escherichia coli, Pseudomonas aeruginosa, Pseudomonas putida) bacteria. Preliminary results showed that six of the twelve synthesized molecules were active against Staphylococcus aureus. Most notable amongst them were compounds 2(2,4-dinitrophenylamino) phenol and 2(2-dinitrophenylamino)phenol having minimum inhibitory concentration (MIC) in the

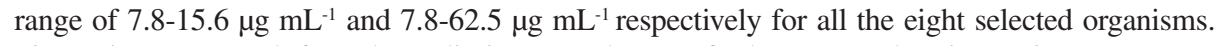
Five active compounds from the preliminary results were further screened against resistant $S$. aureus cultures where compounds 2(2,4-dinitrophenylamino)phenol, 2(2-dinitrophenylamino)phenol and 2-chloro- $N$-(2-(2,4-dichlorophenylamino)phenyl)acetamide gave encouraging results having MIC in the range 3.9-7.8 $\mu \mathrm{g} \mathrm{mL}^{-1}$ for most of the organisms. Results obtained above for the selected organisms and the resistant $S$. aureus strains conclude that hydroxyl group at 2-position of ring B potentiates the antibacterial activity and overcomes the antibiotic resistance.
\end{abstract}

Keywords: infectious diseases, enoyl-acyl carrier protein (ACP) reductases, Staphylococcus aureus, resistant strains, cefepime

\section{Introduction}

Infectious diseases remain the main cause of human premature deaths and account for 15 million cases per year worldwide. ${ }^{1}$ Among these, the infections caused by Staphylococcus aureus (Sau) are ubiquitous, life threatening and a serious public health issue. ${ }^{2}$ The highly infectious pathogen is carried by thirty percent of healthy people, usually in the anterior nasal cavities and is the most common causative agents of nosocomial infections. ${ }^{3}$ It readily gets transferred to immune compromised patients causing post-surgical wound infections. ${ }^{4}$ One of the effective treatments in the past for the infections caused by Staphylococcus aureus was penicillin that later became resistant due to evolution of penicillinase by the organism. Celbenin, commonly known as methicillin, was introduced in 1959 to combat the penicillin resistant microbes. Within one year after its introduction methicillin resistant Staphylococcus aureus (MRSA) was reported..$^{5}$ The spread of MRSA infection over the decades is treated by vancomycin. ${ }^{6}$ The isolation of vancomycin-resistant Staphylococcus aureus (VRSA)

*e-mail: mchhibber@thapar.edu strains in 2002 has once again necessitated the need to continuously discover new drugs to combat such organisms. ${ }^{7}$

Technological advances in genomics have enabled researchers to look more comprehensively at biological systems, resulting in the discovery of a number of novel drug targets. ${ }^{8}$ Bacterial fatty acid biosynthesis, which is type II fatty acid synthesis (FAS-II), is one of the essential pathways in which each reaction is performed by individual enzymes and is fundamentally distinct from the multienzyme complex, FAS-I (type I fatty acid synthesis), found in mammals. The enoyl-acyl carrier protein reductases (Fab I) of FAS II has been the target of a number of studies. ${ }^{9}$ Triclosan, a diphenyl ether, was initially thought to be a nonspecific antiseptic but was later found to target Fab I. ${ }^{10}$ Triclosan resistant enzymes have been found in certain organisms (Fab K, Fab L, and Fab V in S. pneumoniae, B. subtilis and Vibrio cholerae). ${ }^{11}$ Never the less, enoyl reductases remain an excellent target for narrow spectrum drug discovery.

Efforts to improve the antibacterial activity of triclosan have involved synthesizing a series of diphenyl ethers with different substituent on both the rings by a number of groups including ours. ${ }^{12,13}$ In the present work, we have synthesized and evaluated the antibacterial effect of diphenyl amines 
which to the best of our knowledge first time shifts focus from diphenyl ethers to diphenyl amines. We contemplate, these compounds target enoyl reductases. Limited reports are available on the antimicrobial activity of diphenylamines. $\mathrm{N}$-phenyanthranilic acid based diphenyl amines have been studied previously, ${ }^{14}$ and recently, diarylamines have also been evaluated for antibacterial and anti fungal activities containing benzo [b] thiophene or pyridine as one of the moieties. ${ }^{15,16}$ The diphenyl amines synthesized here were initially screened for their antibacterial activity against both Gram-positive (Staphylococcus aureus, Bacillus subtilis, Staphylococcus epidermidis) and Gram-negative (Escherichia coli, Pseudomonas aeruginosa, Pseudomonas putida) strains. Most of the compounds displayed antibacterial activity against Staphylococcus aureus, and some even displayed activity against resistant strains.

\section{Experimental}

Purified reagents were procured from SD Fine Chemicals (Bombay, India). Solvents were distilled before use in column chromatography. Melting points are reported in ${ }^{\circ} \mathrm{C}$ and are uncorrected. ${ }^{1} \mathrm{H}$ and ${ }^{13} \mathrm{C}$ NMR spectral analyses were performed on 400.1 and $100.6 \mathrm{MHz}$ spectrometer (Avance-II (Bruker), Panjab University, Chandigarh, India) with tetramethylsilane and $\mathrm{CDCl}_{3}$ as the internal standard $(\delta, \mathrm{ppm})$ respectively. The following abbreviations were used to explain the multiplicities: $\mathrm{s}$, singlet; d, doublet; $\mathrm{t}$, triplet; dd, double doublet; m, multiplet, br, broad. Mass spectrometry analysis was done using mass spectrometer (Waters Micromass Q-Tof Micro, Panjab University, Chandigarh, India). Scheme 1 summarizes all the synthetic procedures.

\section{Synthesis of 2,4-dinitro- $N$-phenylaniline (1a)}

Although commercially available, we synthesized the compound using 1-fluoro-2,4-dinitrobenzene (186 mg, 1 mmol) and aniline (91 $\mu \mathrm{L}, 1 \mathrm{mmol})$ in dimethyl sulfoxide (DMSO) $(1 \mathrm{~mL})$ by heating in oil bath at $100^{\circ} \mathrm{C}$ for $16 \mathrm{~h}$ under inert atmosphere. On cooling the reaction mixture was partitioned between ethyl acetate $(15 \mathrm{~mL})$ and water $(15 \mathrm{~mL})$ and extracted again with ethyl acetate $(5 \mathrm{~mL})$. The combined organic layers were dried over $\mathrm{Na}_{2} \mathrm{SO}_{4}$, filtered and evaporated in vacuo to yield crude product that was purified by silica gel column chromatography and solvent system (petroleum ether/ethyl acetate, $85: 15, \mathrm{v} / \mathrm{v}$ ) to get orange solid in $85 \%$ yield; m.p. $164{ }^{\circ} \mathrm{C} ;{ }^{1} \mathrm{H}$ NMR $\left(400.1 \mathrm{MHz}, \mathrm{CDCl}_{3}\right)$ $\delta 7.2(\mathrm{~d}, 1 \mathrm{H}, J 9.56 \mathrm{~Hz}, \mathrm{Ar}-\mathrm{H}), 7.3$ (d, 2H, J7.56 Hz, Ar-H), 7.4 (dd, 1H, J 7.48, $1.00 \mathrm{~Hz}$, Ar-H), 7.5 (m, 2H, Ar-H), 8.2 (m, 1H, Ar-H), 9.2 (d, 1H, J 2.64 Hz, Ar-H), 9.9 (s, 1H, NH); ${ }^{13} \mathrm{C}$ NMR $\left(100.6 \mathrm{MHz}, \mathrm{CDCl}_{3}\right) \delta 116.07,124.13,125.55$ (intensity), 127.78, 129.96, 130.29 (intensity), 131.10, 136.68, 137.40, 147.15; Electrospray, ESI-MS, calcd. for $\mathrm{C}_{12} \mathrm{H}_{9} \mathrm{~N}_{3} \mathrm{O}_{4}: m / z 259[\mathrm{M}]^{+}$, found: $m / z 261[\mathrm{M}+2]^{+}$.

\section{Synthesis of compounds $\mathbf{1 b}, \mathbf{1 c}$, and $\mathbf{1 d}$}

To a solution of nitro fluoro benzene $(7.5 \mathrm{mmol})$ in dimethylformamide (DMF) (3 mL) was added relevent<smiles>[R]c1ccc([R])c([R])c1</smiles><smiles>[R]c1ccc(Nc2ccccc2[R])c([R])c1</smiles>

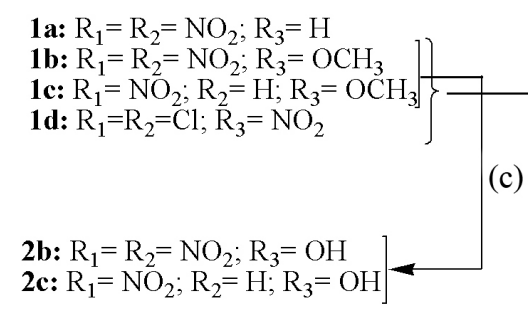


aryl amine $(5 \mathrm{mmol})$, potassium carbonate $(10 \mathrm{mmol})$, cuprous iodide $(0.5 \mathrm{mmol})$ and L-proline $(1.0 \mathrm{mmol})$. The reaction mixture was heated at $100{ }^{\circ} \mathrm{C}$ for $24 \mathrm{~h}$. After completion of the reaction (thyn layer chromatography, TLC, monitoring) it was allowed to cool. Work up was done by adding water $(7 \mathrm{~mL})$ and organic components extracted using ethyl acetate $(3 \times 10 \mathrm{~mL})$. Combined organic solvent was washed with water till it gets neutral ( $\mathrm{pH}$ paper) and dried over brine and $\mathrm{Na}_{2} \mathrm{SO}_{4}$. Evaporation of the organic solvent gave the crude product that was purified using silica column and solvent system (petroleum ether/ethyl acetate, $75: 25$, v/v). Evaporation of the solvent gave pure products that were characterized using ${ }^{1} \mathrm{H},{ }^{13} \mathrm{C}$ NMR spectroscopy and mass spectrometry.

\section{2-Methoxy- $N$-(2,4-dinitrophenyl)-aniline (1b)}

Orange solid in $84 \%$ yield; m.p. $162{ }^{\circ} \mathrm{C} ;{ }^{1} \mathrm{H}$ NMR $\left(400.1 \mathrm{MHz}, \mathrm{CDCl}_{3}\right) \delta 3.8\left(\mathrm{~s}, 3 \mathrm{H}, \mathrm{CH}_{3}\right), 6.98(\mathrm{~m}, 2 \mathrm{H}$, Ar-H), 7.0 (d, 1H, J 9.52 Hz, Ar-H), 7.3 (m, 2H, Ar-H), 8.1 (dd, 1H, J 9.54, 2.52 Hz, Ar-H), 9.1 (d, 1H, J 2.64 Hz, Ar-H), $9.8(\mathrm{~s}, 1 \mathrm{H}, \mathrm{NH}) ;{ }^{13} \mathrm{C} \mathrm{NMR}\left(100.6 \mathrm{MHz}, \mathrm{CDCl}_{3}\right) \delta 55.75$, $112.05,116.29,121.05,124.06,125.39,125.48,128.49$, 129.68, 131.37, 137.24, 146.81, 153.45; ESI-MS, calcd. for $\mathrm{C}_{13} \mathrm{H}_{11} \mathrm{~N}_{3} \mathrm{O}_{5}: m / z 289[\mathrm{M}]^{+}$, found: $m / z 290[\mathrm{M}+\mathrm{H}]^{+}$.

\section{2-Methoxy- $N$-(2-nitrophenyl)-aniline (1c)}

Orange solid in $80 \%$ yield; m.p. $87{ }^{\circ} \mathrm{C} ;{ }^{1} \mathrm{H}$ NMR $\left(400.1 \mathrm{MHz}, \mathrm{CDCl}_{3}\right) \delta 3.9$ (s, 3H, $\left.\mathrm{CH}_{3}\right), 6.8$ (m, 1H, Ar-H), 6.89 (m, 2H, Ar-H), 7.2 (m, 1H, Ar-H), 7.3 (m, 1H, Ar-H), 7.4 (m, 2H, Ar-H), 8.2 (dd, 1H, J 8.56, $1.6 \mathrm{~Hz}, \mathrm{Ar}-\mathrm{H})$, $9.4(\mathrm{~s}, 1 \mathrm{H}, \mathrm{NH}) ;{ }^{13} \mathrm{C} \mathrm{NMR}\left(100.6 \mathrm{MHz}, \mathrm{CDCl}_{3}\right) \delta 55.71$, 111.60, 116.21, 117.44, 120.67, 123.29, 125.77, 126.68, 127.84, 133.76, 135.46, 142.50, 152.53; ESI-MS, calcd. for $\mathrm{C}_{13} \mathrm{H}_{12} \mathrm{~N}_{2} \mathrm{O}_{3}: m / z 244[\mathrm{M}]^{+}$, found: $m / z 245[\mathrm{M}+\mathrm{H}]^{+}$.

\section{2,4-Dichloro- $N$-(2-nitrophenyl)-aniline (1d)}

Orange solid in $82 \%$ yield; m.p. $115{ }^{\circ} \mathrm{C} ;{ }^{1} \mathrm{H}$ NMR (400.1 MHz, $\left.\mathrm{CDCl}_{3}\right) \delta 6.9(\mathrm{t}, 1 \mathrm{H}, J 7.84 \mathrm{~Hz}, \mathrm{Ar}-\mathrm{H}), 7.1$ (dd, 1H, J8.6, 1.2 Hz, Ar-H), 7.3 (d, 1H, J $2.32 \mathrm{~Hz}$, Ar-H), 7.4 (d, 1H, J 8.6 Hz, Ar-H), 7.4 (m, 1H, Ar-H), 7.5 (d, 1H, $J 2.36 \mathrm{~Hz}, \mathrm{Ar}-\mathrm{H}), 8.2$ (dd, 1H, J 8.54, $1.52 \mathrm{~Hz}, \mathrm{Ar}-\mathrm{H}), 9.4$ (s, $1 \mathrm{H}, \mathrm{NH}) ;{ }^{13} \mathrm{C} \mathrm{NMR}\left(100.6 \mathrm{MHz}, \mathrm{CDCl}_{3}\right) \delta 112.06,116.30$, 121.05, 124.06, 125.37, 125.48, 128.49, 129.69, 131.37, 137.22, 150.01, 153.45; ESI-MS, calcd. for $\mathrm{C}_{12} \mathrm{H}_{8} \mathrm{~N}_{2} \mathrm{O}_{2} \mathrm{Cl}_{2}$ : $m / z, 282[\mathrm{M}]^{+}$, found: $m / z, 282[\mathrm{M}]^{+}$.

\section{Synthesis of compounds $\mathbf{2 b}$ and $\mathbf{2 c}$}

To the compound obtained above, $\mathbf{1 b}$ and $\mathbf{1 c},(0.62 \mathrm{mmol})$ in acetic acid $(10 \mathrm{~mL})$ was added $48 \%$ aqueous $\mathrm{HBr}(1 \mathrm{~mL})$ and heated under reflux for $2 \mathrm{~h}$. After confirming completion of the reaction (TLC monitoring) it was cooled to room temperature and acetic acid evaporated in vacuo. Water $(5 \mathrm{~mL})$ was added to dissolve the contents and the aqueous layer extracted with ethyl acetate $(3 \times 10 \mathrm{~mL})$. The combined organic layers were dried over $\mathrm{Na}_{2} \mathrm{SO}_{4}$. Evaporation of the organic solvent gave product which was purified using silica column chromatography and solvent system (pet ether/ethyl acetate, $65: 35, \mathrm{v} / \mathrm{v}$ ) to afford desired compounds.

\section{2-(2,4-Dinitrophenylamino)-phenol (2b)}

Dark brown solid in $45 \%$ yield; m.p. $142{ }^{\circ} \mathrm{C} ;{ }^{1} \mathrm{H}$ NMR $\left(400.1 \mathrm{MHz}, \mathrm{CDCl}_{3}\right) \delta 5.7(\mathrm{~s}, 1 \mathrm{H}, \mathrm{OH}), 6.75(\mathrm{dd}, 1 \mathrm{H}$, $J$ 8.6, $1.12 \mathrm{~Hz}, \mathrm{Ar}-\mathrm{H}), 6.86(\mathrm{~m}, 1 \mathrm{H}, \mathrm{Ar}-\mathrm{H}), 7.1$ (m, 1H, Ar-H), 7.3 (dd, 1H, J 5.88, $3.88 \mathrm{~Hz}, \mathrm{Ar}-\mathrm{H}$ ), 7.4 (m, 1H, Ar-H), 8.2 (dd, 1H, J 8.56, $1.56 \mathrm{~Hz}, \mathrm{Ar}-\mathrm{H}), 8.9$ (s, 1H, NH); ${ }^{13} \mathrm{C} \mathrm{NMR}\left(100.6 \mathrm{MHz}, \mathrm{CDCl}_{3}\right) \delta 116.14,118.55,119.72$, 121.46, 124.33, 124.64, 126.68, 128.91, 136.24, 143.43, 152.97; ESI-MS, calcd. for $\mathrm{C}_{12} \mathrm{H}_{9} \mathrm{~N}_{3} \mathrm{O}_{5}: \mathrm{m} / z, 275[\mathrm{M}]^{+}$, found: $m / z, 276[\mathrm{M}+\mathrm{H}]^{+}$.

\section{2-(2-Nitrophenylamino)-phenol (2c)}

Dark brown solid in $37 \%$ yield; m.p. $141{ }^{\circ} \mathrm{C} ;{ }^{1} \mathrm{H}$ NMR $\left(400.1 \mathrm{MHz}, \mathrm{CDCl}_{3}\right) \delta 5.7$ (br-s, $\left.1 \mathrm{H}, \mathrm{OH}\right), 6.7(\mathrm{~d}, 1 \mathrm{H}$, $J 8.48 \mathrm{~Hz}, \mathrm{Ar}-\mathrm{H}), 6.9(\mathrm{~m}, 1 \mathrm{H}), 7.1(\mathrm{~m}, 2 \mathrm{H}, \mathrm{Ar}-\mathrm{H}), 7.3(\mathrm{~d}$, 1H, J 4.6 Hz, Ar-H), 7.4 (m, 1H, Ar-H), 8.2 (dd, 1H, J 6.88, $1.8 \mathrm{~Hz}, \mathrm{Ar}-\mathrm{H}), 8.4$ (d, 1H, J $2.32 \mathrm{~Hz}, \mathrm{Ar}-\mathrm{H}), 8.9$ (s, 1H, $\mathrm{NH}) ;{ }^{13} \mathrm{C} \mathrm{NMR}\left(100.6 \mathrm{MHz}, \mathrm{CDCl}_{3}\right) \delta 116.10,118.52$, 119.67, 121.46, 124.37, 124.73, 126.66, 128.92, 136.25, 138.91,143.41,152.70; ESI-MS, calcd. for $\mathrm{C}_{12} \mathrm{H}_{10} \mathrm{~N}_{2} \mathrm{O}_{3}: \mathrm{m} / z$ $230[\mathrm{M}]^{+}$, found: $m / z 231[\mathrm{M}+\mathrm{H}]^{+}$.

\section{Synthesis of compounds $\mathbf{2 d}, \mathbf{2 e}$ and $\mathbf{2 f}$}

To a suspension of nitro diphenyl amines $\mathbf{1 b}, \mathbf{1 c}$ and $\mathbf{1 d}$ (10.6 mmol) in $\mathrm{H}_{2} \mathrm{O}(50 \mathrm{~mL})$ was added $\mathrm{Fe}$ (106.2 mmol) and $\mathrm{FeSO}_{4} \cdot 7 \mathrm{H}_{2} \mathrm{O}(10.4 \mathrm{mmol})$. The reaction mixture was refluxed for $8 \mathrm{~h}$. After confirming the completion of reaction (TLC monitoring), it was cooled and filtered through celite. The organic components were extracted with ethyl acetate $(2 \times 75 \mathrm{~mL})$. The combined organic layers were dried over $\mathrm{Na}_{2} \mathrm{SO}_{4}$. Evaporation of the organic solvent gave crude amino product that was purified using silica column and solvent system (pet ether/ethyl acetate, $80: 20, \mathrm{v} / \mathrm{v})$. Evaporation of the solvent gave pure product that was characterized using ${ }^{1} \mathrm{H},{ }^{13} \mathrm{C}$ NMR spectroscopy and mass spectrometry.

$N^{1}$-(2-methoxyphenyl)-benzene-1,2,4-triamine (2d)

Dark brown solid in $65 \%$ yield; m.p. $59{ }^{\circ} \mathrm{C} ;{ }^{1} \mathrm{H}$ NMR (400.1 MHz, $\mathrm{CDCl}_{3}$ ) $\delta$ 3.6-3.7 (br s, 4H, 2NH ), 3.8 (s, 3H, $\left.\mathrm{OCH}_{3}\right), 5.4$ (s, 1H, NH), 6.1 (m, 2H, Ar-H), 6.6 (dd, 1H, 
J 7.72, $1.52 \mathrm{~Hz}, \mathrm{Ar}-\mathrm{H}), 6.7-6.8(\mathrm{~m}, 4 \mathrm{H}, \mathrm{Ar}-\mathrm{H}) ;{ }^{13} \mathrm{C} \mathrm{NMR}$ $\left(100.6 \mathrm{MHz}, \mathrm{CDCl}_{3}\right) \delta 55.51,102.19,106.14,109.78$, 111.89, 117.40, 118.81, 121.23, 129.07, 136.94, 144.90, 145.51, 146.83; ESI-MS, calcd. for $\mathrm{C}_{13} \mathrm{H}_{15} \mathrm{~N}_{3} \mathrm{O}: \mathrm{m} / z 229$ $[\mathrm{M}]^{+}$, found: $m / z, 230[\mathrm{M}+\mathrm{H}]^{+}$.

\section{$N^{\prime}$-(2-methoxyphenyl)-benzene-1,2-diamine (2e)}

Dark brown solid in $63 \%$ yield; m.p. $120^{\circ} \mathrm{C} ;{ }^{1} \mathrm{H}$ NMR $\left(400.1 \mathrm{MHz}, \mathrm{CDCl}_{3}\right) \delta 3.8$ (br-s, $2 \mathrm{H}, \mathrm{NH}_{2}$ ), 3.9 (s, $3 \mathrm{H}$, $\left.\mathrm{OCH}_{3}\right), 5.7(\mathrm{~s}, 1 \mathrm{H}, \mathrm{NH}), 6.6(\mathrm{dd}, 1 \mathrm{H}, J$ 7.48, $1.88 \mathrm{~Hz}, \mathrm{Ar}-\mathrm{H})$, 6.8 (m, 4H, Ar-H), 6.9 (dd, 1H, J 7.56, $1.72 \mathrm{~Hz}, \mathrm{Ar}-\mathrm{H}), 7.0$ (m, 1H, Ar-H), 7.1 (dd, $1 \mathrm{H}, J 7.8,1.36 \mathrm{~Hz}$, Ar-H); ${ }^{13} \mathrm{C}$ NMR $\left(100.6 \mathrm{MHz}, \mathrm{CDCl}_{3}\right) \delta 55.56,110.05,113.03,115.97$, 118.44, 119.01, 121.09, 125.35, 125.73, 128.18, 135.13, 142.43, 147.33; ESI-MS, calcd. for $\mathrm{C}_{13} \mathrm{H}_{14} \mathrm{~N}_{2} \mathrm{O}: m / z 214$ $[\mathrm{M}]^{+}$, found: $m / z, 215[\mathrm{M}+\mathrm{H}]^{+}$.

\section{$N^{\prime \prime}$-(2,4-dichlorophenyl)benzene-1,2-diamine (2f)}

Black solid in $62 \%$ yield; m.p. $84{ }^{\circ} \mathrm{C}$; ${ }^{1} \mathrm{H}$ NMR $\left(400.1 \mathrm{MHz}, \mathrm{CDCl}_{3}\right) \delta 3.9$ (br-s, $\left.2 \mathrm{H}, \mathrm{NH}_{2}\right), 5.7(\mathrm{~s}, 1 \mathrm{H}$, $\mathrm{NH}), 6.5(\mathrm{~d}, 1 \mathrm{H}, J 8.76 \mathrm{~Hz}, \mathrm{Ar}-\mathrm{H}), 6.8(\mathrm{~m}, 1 \mathrm{H}, \mathrm{Ar}-\mathrm{H})$, 7.0 (dd, 1H, J 8.8, 2.4 Hz, Ar-H), 7.1 (m, 2H, Ar-H), 7.3 (d, $1 \mathrm{H}, J 8.48 \mathrm{~Hz}, \mathrm{Ar}-\mathrm{H}) ;{ }^{13} \mathrm{C}$ NMR $\left(100.6 \mathrm{MHz}, \mathrm{CDCl}_{3}\right)$ $\delta 114.79,116.18,119.12,120.06,123.01,126.01,127.00$, 127.37, 127.73, 128.89, 140.83, 143.10; ESI-MS, calcd. for $\mathrm{C}_{12} \mathrm{H}_{10} \mathrm{~N}_{2} \mathrm{Cl}_{2}: m / z 252[\mathrm{M}]^{+}$, found: $m / z, 253[\mathrm{M}+\mathrm{H}]^{+}$.

\section{Synthesis of compounds $\mathbf{3 f 1}, \mathbf{3 f 2}$ and $\mathbf{3 f 3}$}

The acid chloride was prepared from corresponding acid $(0.5 \mathrm{mmol})$ and $\mathrm{PCl}_{3}(0.5 \mathrm{mmol})$ by heating and stirring at $60-70{ }^{\circ} \mathrm{C}$ till the evolution of hydrochloric acid gas ceased. The acid chloride thus prepared was added to a stirred solution of compound $2 \mathbf{f}(0.5 \mathrm{mmol}), \mathrm{K}_{2} \mathrm{CO}_{3}(0.3 \mathrm{mmol})$ in dicloromethane, $\mathrm{DCM},(10 \mathrm{~mL})$ at $0^{\circ} \mathrm{C}$. The reaction mixture was stirred for $2 \mathrm{~h}$ and quenched with water. The organic product was extracted with DCM $(3 \times 50 \mathrm{~mL})$, dried over $\mathrm{Na}_{2} \mathrm{SO}_{4}$, and concentrated in vacuo. Crude product obtained was purified using silica column and solvent system (pet ether/ ethyl acetate, 70:30, v/v) to afford light brown solids.

\section{$\mathrm{N}$-(2-(2,4-dichlorophenylamino)phenyl)acetamide (3f1)}

Light Brown solid in $66 \%$ yield; m.p. $119^{\circ} \mathrm{C}$; ${ }^{1} \mathrm{H}$ NMR $\left(400.1 \mathrm{MHz}, \mathrm{CDCl}_{3}\right) \delta 2.1\left(\mathrm{~s}, 3 \mathrm{H}, \mathrm{CH}_{3}\right), 6.2(\mathrm{~s}, 1 \mathrm{H}, \mathrm{NH})$, 6.6 (d, 1H, J $8.76 \mathrm{~Hz}, \mathrm{Ar}-\mathrm{H}), 7.0$ (dd, 1H, J 8.76, $2.24 \mathrm{~Hz}$, Ar-H), 7.2 (m, 3H, Ar-H), 7.3 (d, 1H, J $2.36 \mathrm{~Hz}, \mathrm{Ar}-\mathrm{H}), 7.7$ (s, 1H, 1NHCO), 7.9 (d, 1H, J 7.54 Hz, Ar-H); ${ }^{13} \mathrm{C}$ NMR $\left(100.6 \mathrm{MHz}, \mathrm{CDCl}_{3}\right) \delta 24.34,115.58,121.31,123.02$, $124.12,125.27,125.76,126.15,127.71,129.22,132.16$, 133.01, 140.53, 169.14; ESI-MS, calcd. for $\mathrm{C}_{14} \mathrm{H}_{12} \mathrm{~N}_{2} \mathrm{OCl}_{2}$ : $\mathrm{m} / z, 294[\mathrm{M}]^{+}$, found: $\mathrm{m} / z 317[\mathrm{M}+\mathrm{Na}]^{+}$.
$\mathrm{N}$-(2-(2,4-dichlorophenylamino)phenyl)propionamide (3f2)

Light brown solid in $69 \%$ yield; m.p. $105{ }^{\circ} \mathrm{C} ;{ }^{1} \mathrm{H}$ NMR $\left(400.1 \mathrm{MHz}, \mathrm{CDCl}_{3}\right) \delta 1.2\left(\mathrm{t}, 3 \mathrm{H}, J 7.6 \mathrm{~Hz}, \mathrm{CH}_{3}\right), 2.3$ (q, $\left.2 \mathrm{H}, J 15.14,7.56 \mathrm{~Hz}, \mathrm{CH}_{2}\right), 6.0(\mathrm{~s}, 1 \mathrm{H}, \mathrm{NH}), 6.5(\mathrm{~d}, 1 \mathrm{H}$, $J 8.76 \mathrm{~Hz}, \mathrm{Ar}-\mathrm{H}), 7.0$ (dd, $1 \mathrm{H}, J$ 8.8, $2.24 \mathrm{~Hz}, \mathrm{Ar}-\mathrm{H}), 7.1$ (m, $1 \mathrm{H}, \mathrm{Ar}-\mathrm{H}), 7.2$ (m, 2H, Ar-H), 7.4 (d, 1H, J $2.36 \mathrm{~Hz}, \mathrm{Ar}-\mathrm{H})$, 7.6 (s, 1H, 1NHCO), 8.0 (d, J 7.8 Hz, Ar-H); ${ }^{13} \mathrm{C}$ NMR $\left(100.6 \mathrm{MHz}, \mathrm{CDCl}_{3}\right) \delta 9.68,30.62,115.35,119.76,121.10$, $122.69,124.08,125.60,126.45,127.71,129.17,131.56$, 133.40, 140.54, 172.59; ESI-MS, calcd. for $\mathrm{C}_{15} \mathrm{H}_{12} \mathrm{~N}_{2} \mathrm{OCl}_{2}$ : $m / z, 308[\mathrm{M}]^{+}$, found: $m / z 309[\mathrm{M}+\mathrm{H}]^{+}$.

2-Chloro- $N$-(2-(2,4-dichlorophenylamino)phenyl)acetamide (3f3)

Light brown solid in $64 \%$ yield; m.p. $80{ }^{\circ} \mathrm{C}$; ${ }^{1} \mathrm{H}$ NMR $\left(400.1 \mathrm{MHz}, \mathrm{CDCl}_{3}\right) \delta 4.1$ (s, 2H, $\left.\mathrm{CH}_{2}\right), 6.0(\mathrm{~s}, 1 \mathrm{H}, \mathrm{NH})$, 6.5 (d, 1H, J 8.76 Hz, Ar-H), 7.0 (dd, $1 \mathrm{H}, J 8.76,2.32 \mathrm{~Hz}$, Ar-H), 7.3 (m, 3H, Ar-H), 7.4 (d, 1H, J 2.36, Ar-H), 8.0 (d, $1 \mathrm{H}, J 7.52 \mathrm{~Hz}, \mathrm{Ar}-\mathrm{H}), 8.7$ (s, 1H, NHCO); ${ }^{13} \mathrm{C}$ NMR $\left(100.6 \mathrm{MHz}, \mathrm{CDCl}_{3}\right) \delta 42.96,115.37,121.31,122.14$, $124.45,125.98,126.23,126.77,127.77,129.24,131.51$, 132.57, 140.25, 164.31; ESI-MS, calcd. for $\mathrm{C}_{14} \mathrm{H}_{11} \mathrm{~N}_{2} \mathrm{OCl}_{3}$ : $m / z 329[\mathrm{M}]^{+}$, found: $m / z 329[\mathrm{M}+\mathrm{H}]^{+}$.

\section{In vitro antimicrobial assay}

\section{Test isolates}

For preliminary screening, the test spectrum consists of standard surrogate Gram-positive and Gram-negative bacteria (Table S1, Supplementary Information). Gram-positive strains included Staphylococcus aureus (NCTC 6571 and MTCC 96), Staphylococcus epidermidis (MTCC 2639) and Bacillus subtilis while Gram-negative strains included Escherichia coli (MTCC 1302), Pseudomonas aeruginosa (MTCC 647 and MTCC 3541) and Pseudomonas putida. Triclosan, a diphenyl ether known to have antibacterial activity $^{10}$ and streptomycin were used as reference compounds.

In vitro microbroth dilution assay to determine minimal inhibitory concentration (MIC)

Stock solutions of the compounds were prepared and tested against a spectrum of standard strains and the clinical isolates of Staphylococcus aureus by in vitro microbroth dilution assay to ascertain antimicrobial potential of the compounds as discribed Clinical and Laboratory Standards Institute (CLSI) M7-A4. ${ }^{17}$

MIC is considered to be the gold standard technique to evaluate the susceptibility of a microorganism to a particular antibiotic and performed as reported earlier. ${ }^{18}$ Briefly $50 \mu \mathrm{L}$ of the $18 \mathrm{~h}$ old $0.5 \mathrm{McFarland}$ adjusted bacterial suspension in physiological saline was dispensed in each well. $125 \mu \mathrm{L}$ 
of $\mathrm{MH}$ broth was added in the wells to achieve a final bacterial cell concentration of $10^{6}$ cells in the well. Plates were incubated at $37^{\circ} \mathrm{C}$ for $2.5 \mathrm{~h}$. Next, $25 \mu \mathrm{L}$ of the test compound at different concentrations (i.e. two fold serial dilutions in range between $62.5-0.48 \mu \mathrm{g} \mathrm{mL}^{-1}$ ) was added into the well and incubated for $24 \mathrm{~h}$ at $37^{\circ} \mathrm{C}$. Subsequently $20 \mu \mathrm{L}$ of $0.02 \%$ of MTT, (3-(4,5-dimethylthiazol-2-yl)-2,5diphenyltetrazolium bromide), was added into each well and incubated at $37{ }^{\circ} \mathrm{C}$ for $1 \mathrm{~h}$. The color change due to formation of formazan was visually observed. All the tests were performed in triplicates.

\section{Results and Discussion}

\section{Chemistry}

Synthesis of all the compounds has been illustrated in Scheme 1. All the initial compounds (1a to 1d) were synthesized by nucleophilic aromatic substitution of nitro fluorobenzene with corresponding anilines. For the synthesis of compound 1a there was no need of base, metal salt or the ligand. Compounds $\mathbf{1 b}, \mathbf{1 c}$ and $\mathbf{1 d}$ were synthesized by a known procedure using potassium carbonate, cuprous iodide and catalytic amount of L-proline under refluxing conditions in aprotic solvent at $100{ }^{\circ} \mathrm{C} .{ }^{19}$ All the three compounds have also been synthesized by alternate routes. ${ }^{20-22}$ The demethylation of compound $\mathbf{1 b}$ and 1c was done by refluxing in $48 \%$ aqueous hydrobromic acid and acetic acid to give corresponding 2-hydroxy diphenyl amines $\mathbf{2 b}$ and $\mathbf{2 c}$ respectively. The disappearance of signals due to methoxy group in ${ }^{1} \mathrm{H}(3.8-3.9 \mathrm{ppm})$ and ${ }^{13} \mathrm{C}$ (55.7 ppm) NMR confirmed this. Earlier reports suggested synthesis of such compounds by Smiles rearrangement. ${ }^{23}$ The nitro groups on compounds $\mathbf{1 b}, \mathbf{1 c}$ and $\mathbf{1 d}$ were reduced to corresponding amines $\mathbf{2 d}, \mathbf{2 e}$ and $\mathbf{2 f}$ by refluxing with powdered iron and ferrous sulfate in aqueous media. ${ }^{24}$ Appearance of broad singlet in the range of 3.6-3.9 ppm in ${ }^{1} \mathrm{H}$ NMR confirmed the presence of amine. The amine $\mathbf{2 f}$ obtained above was converted into novel compounds $\mathbf{3 f 1}$, $\mathbf{3 f} \mathbf{2}$ and $\mathbf{3 f} \mathbf{3}$ by reacting with corresponding acid chlorides in the presence of potassium carbonate and methylene chloride. This was confirmed by presence of signal in the range of $164-173 \mathrm{ppm}$ in ${ }^{13} \mathrm{C}$ NMR due to carbonyl carbon of amide groups. The acid chlorides used were freshly prepared by treating acetic acid, proponic acid and chloroacetic acid with phosphorous trichloride.

\section{Biological activity}

Antibacterial screening was carried out against eight organisms comprising both Gram-positive and Gram- negative bacteria. Gram-positive microorganisms included two strains of Staphylococcus aureus and one strain each of Staphylococcus epidermidis and Bacillus subtilis while Gram-negative included two strains of Pseudomonas aeruginosa and one strain each of Escherichia coli and Pseudomonas putida. Preliminary results (Table S1, Supplementary Information) showed that 6 of the 13 compounds were active against Staphylococcus aureus that have been summarized in Table 1. Against the remaining strains three compounds (1a, $\mathbf{2 b}$ and $\mathbf{2 c}$ ) gave encouraging results. Gram-negative, Pseudomonas putida was an exception to this as it was inhibited by all the synthesized compounds except compounds $\mathbf{2 d}$ and 2e, with MICs ranging from $7.8-62.5 \mu \mathrm{g} \mathrm{mL}^{-1}$.

Table 1. MIC values of diphenylamines in $\mu \mathrm{g} \mathrm{mL}^{-1}$ against reference strains of Staphylococcus aureus

\begin{tabular}{lcc}
\hline Compound & $\begin{array}{c}\text { S. aureus } \\
\text { (NCTC 6571) }\end{array}$ & $\begin{array}{c}\text { S. aureus } \\
\text { (MTCC 96) }\end{array}$ \\
\hline Streptomycin $^{\mathrm{a}}$ & - & - \\
Triclosan $^{\mathrm{a}}$ & 7.8 & 3.90 \\
$\mathbf{1 a}$ & 15.6 & 15.6 \\
$\mathbf{1 d}$ & 15.6 & 7.8 \\
$\mathbf{2 b}$ & 7.8 & 7.8 \\
$\mathbf{2 c}$ & 31.2 & 31.2 \\
$\mathbf{2 f}$ & 15.6 & 31.2 \\
$\mathbf{3 f 3}$ & 31.2 & 7.8 \\
\hline
\end{tabular}

${ }^{a}$ Streptomycin and triclosan were used as reference compound.

Most notable among all, were the compounds $\mathbf{2 b}$ and $\mathbf{2 c}$ as both were active against all the selected stains. Compound $\mathbf{2 b}$ having MIC in the range 7.8-15.6 $\mu \mathrm{g} \mathrm{mL}^{-1}$ was the most effective as it gave antibacterial activity comparable to that of control against all the organisms. Compound 2c, athough it displayed a higher MIC range, (7.8-62.5 $\mu \mathrm{g} \mathrm{mL}^{-1}$ ) was also active against all the organisms. Triclosan and streptomycin, used as control compounds, had MICs in the range of 1.9-7.8 $\mu \mathrm{g} \mathrm{mL}^{-1}$ and 1.9-15.6 $\mu \mathrm{g} \mathrm{mL}^{-1}$, respectively, in the preliminary studies. Whereas triclosan was active against all the strains Streptomycin did not give encouraging results against many stains including Staphylococcus aureus. A common feature of both the compounds $\mathbf{2 b}$ and $\mathbf{2 c}$ is the presence of hydroxyl group $(\mathrm{OH})$ at ortho position of ring $\mathrm{B}$.

Similarly, compounds with 2,4-dichlorosubstitution on ring A were also effective against $S$. aureus strains. Table 1 shows the MIC range of compounds, $\mathbf{1 d}\left(7.8-15.6 \mu \mathrm{g} \mathrm{mL}^{-1}\right)$, 2f (15.6-31.2 $\left.\mu \mathrm{g} \mathrm{mL}^{-1}\right)$ and $3 \mathbf{3 f}\left(7.8-31.2 \mu \mathrm{g} \mathrm{mL}^{-1}\right)$. Compound 1d, in addition to inhibiting $S$. aureus strains, was also active against three Gram-negative strains 
having MIC in the range 31.2-62.5 $\mu \mathrm{g} \mathrm{mL}^{-1}$ (Table S1, Supplementary Information). However, compounds $2 \mathbf{2 f}$ and $\mathbf{3 f 3}$ were active only against $P$ seudomonas putida in Gramnegative bacteria. While compound 1a showed inhibitory activity against $S$. aureus, it was more effective against Pseudomonas putida with a MIC value of $7.8 \mu \mathrm{g} \mathrm{mL}^{-1}$.

Based on the results of initial screening against $S$. aureus (Table 1), five of seven active compounds $\mathbf{2 b}$, $\mathbf{2 c}, \mathbf{1 d}, \mathbf{2 f}$ and $\mathbf{3 f 3}$, were tested against resistant strains of S. aureus for their antibacterial activity.

\section{Structure activity relationship}

Results in Table 1 and Table $\mathrm{S} 1$ indicate that the presence of hydroxyl group at 2-position of ring B is essential for the enhanced antibacterial activity. This is evident from the fact that two compounds $\mathbf{2 b}$ and $\mathbf{2 c}$, having hydroxyl group at the said position, have shown good activity against all the Gram-positive and Gram-negative strains taken in this study. MIC range for compound $\mathbf{2 b}$ was $7.8-15.6 \mu \mathrm{g} \mathrm{mL}^{-1}$ and for compound $\mathbf{2 c}$ was $7.8-62.5 \mu \mathrm{g} \mathrm{mL}^{-1}$. Whereas compound $\mathbf{2 b}$ gave MIC value of $7.8 \mu \mathrm{g} \mathrm{mL} \mathrm{m}^{-1}$ against all the strains except Bacillus subtilis and S. epidermidis, compound 2c was comparatively less active having giving MIC values in the range of 7.8-62.5 $\mu \mathrm{g} \mathrm{mL}^{-1}$. Thus, the presence of two nitro groups at position 2 and 4 of ring A enhances the antibacterial activity of diphenyl amines as compared to only one at 2-position. All other compounds containing methoxy group at 2-position of ring $B$ in diphenyl amines (1b, 1c, 2d, 2e) did not yield any antibacterial activity. Earlier reports have established that the 2-hydroxy group is essential for the inhibition of enoyl-ACP reductases (Fab I). ${ }^{25}$ The study carried out with $N$-(2,4-dichlorophenyl)-2-methoxyaniline and $N$-(2,4-dichlorophenyl)-2-hydroxyaniline shows inhibition of enoyl-ACP reductases (FabI) of P. falciparum due to the formation of a ternary complex at the active site of the enzyme with the latter compound. Our study also corroborates with reported results and therefore it can be proposed that Fab I may be the possible target of compounds $\mathbf{2 b}$ and $\mathbf{2 c}$.

Compound 1a, having neither methoxy nor hydroxyl substituent at 2-position of ring B, showed comparatively better results than compounds having methoxy group at the said position (compounds $\mathbf{1 b}, \mathbf{1 c}, \mathbf{2 d}$ and $\mathbf{2 e}$ ). It showed antibacterial activity against Staphylococcus aureus, Staphylococcus epidermidis, Escherichia coli and Pseudomonas putida with MIC values in the range of 7.8-31.2 $\mu \mathrm{g} \mathrm{mL}^{-1}$. This shows that methoxy group at 2-position of ring B is intolerable as compared to hydroxyl or hydrogen for the antibacterial activity.
Compounds $\mathbf{1 d}$ and 2f, having polar nitro and amino groups respectively at 2-position of diphenyl amine in the ring $\mathrm{B}$ and chloro groups at positions 2 and 4 of ring A, did not display broad spectrum inhibitory activity like compounds $\mathbf{2 b}$ and $\mathbf{2 c}$. However, both demonstrated good antibacterial activity against Staphylococcus aureus. Compound 1d, having a nitro group at 2-position, demonstrated better MIC range of 7.8-15.6 $\mu \mathrm{g} \mathrm{mL}^{-1}$ as compared to amino containing compound $2 \mathbf{f}$ which had MICs in the range 3.9-31.2 $\mu \mathrm{gL}^{-1}$. The former compound was also active against Escherichia coli and Pseudomonas aeruginosa, but at higher concentrations. Thus, although 2,4-dichloro diphenyl amines in compounds $\mathbf{1 d}$ and $\mathbf{2 f}$ have shown promise for antibacterial activity, further exploratory studies on the B ring are required to optimize for broad spectrum antibacterial activity.

Functionalization of amino group in compound $\mathbf{2 f}$ with acid chlorides gave the corresponding amides $\mathbf{3 f 1} \mathbf{3 f 2}$ and $\mathbf{3 f 3}$. However, except for $\mathbf{3 f 3}$, these were found to be ineffective against all the strains other than Pseudomonas putida. Thus, amidation of amino group at 2-position of ring $\mathrm{B}$ further obliterates the antibacterial activity. However, the activity is regained by amidation with chloro acetic acid as in the case of compound 3f3. P. putida was the most sensitive among all the strains that were selected for the study.

Compounds $\mathbf{2} \mathbf{d}$ and $\mathbf{2} \mathbf{e}$ do not have any of the required features as discussed above and were ineffective against all the strains including sensitive $P$. putida. They have unfavorable features includeding the presence of methoxy group and the presence of amino group at ortho positions.

\section{Antibacterial activity against resistant strains}

As discussed above five compounds (1d, $\mathbf{2 b}, \mathbf{2 c}, \mathbf{2 f}$ and 3f3) were shortlisted for screening against resistant strains of S. aureus (Sau) with Sau NCTC 6571 and Sau MTCC 737 as reference strains and triclosan and cefepime as control drugs. Table 2 shows MIC of cefepime in the range of $40-160 \mu \mathrm{g} \mathrm{mL}^{-1}$ for the selected strains. The MIC range of cefepime against $S$. aureus (sensitive) and $S$. aureus (resistance) is between $0.007-8 \mu \mathrm{g} \mathrm{mL}{ }^{-1} .^{26}$ The resistance profiles of the organisms are listed in Table 2. A total of seventeen (out of twenty) strains shown in Table 2 are resistant against methicillin, vancomycin, vancomycin intermediate or multi-antibiotic.

Antibacterial activity against the strains (Table 2) demonstrate that compound $\mathbf{2 b}$ having nitro groups at 2 and 4 position of ring $\mathrm{A}$ was the most effective having MIC value in the range of 3.9-7.8 $\mu \mathrm{g} \mathrm{mL}^{-1}$ for most of the resistant organisms. This was followed by slightly 
Table 2. Screening of diphenyl amines against resistant $S$. aureus cultures

\begin{tabular}{|c|c|c|c|c|c|c|c|c|}
\hline \multirow[t]{2}{*}{ Culture code } & \multirow[t]{2}{*}{ Source } & 1d & $2 \mathbf{b}$ & $2 c$ & $2 f$ & $\mathbf{3 f 3}$ & $\begin{array}{l}\text { Triclosan } \\
\text { (control 1) }\end{array}$ & $\begin{array}{l}\text { Cefepime } \\
\text { (control 2) }\end{array}$ \\
\hline & & \multicolumn{7}{|c|}{$\mathrm{MIC} /\left(\mu \mathrm{g} \mathrm{mL}^{-1}\right)$} \\
\hline Sau G $1^{\mathrm{a}}$ & Pus $^{f}$ & 3.9 & 7.8 & 7.8 & 31.2 & 15.6 & 7.8 & 160 \\
\hline Sau G $2^{\mathrm{b}, \mathrm{c}}$ & $\operatorname{Pus}^{\mathrm{f}}$ & - & 7.8 & 15.6 & - & - & 3.9 & 160 \\
\hline Sau G $3^{\text {b,d }}$ & $\operatorname{Pus}^{\mathrm{f}}$ & 15.6 & 3.9 & 3.9 & 31.2 & 15.6 & 3.9 & 160 \\
\hline Sau G $10^{\mathrm{b}, \mathrm{c}}$ & Pus $^{\mathrm{f}}$ & 7.8 & 3.9 & 7.8 & 15.6 & 15.6 & 3.9 & 160 \\
\hline Sau G $4^{\mathrm{b}, \mathrm{c}}$ & Urine $^{f}$ & 7.8 & 7.8 & 15.6 & 7.8 & 7.8 & 7.8 & 160 \\
\hline Sau G $5^{c}$ & Urine $^{f}$ & 7.8 & 3.9 & 7.8 & 15.6 & 15.6 & 7.8 & 160 \\
\hline Sau G $11^{\mathrm{b}, \mathrm{c}}$ & Urine $^{f}$ & 3.9 & 3.9 & 7.8 & 31.2 & 15.6 & 7.8 & 160 \\
\hline Sau G $9^{b}$ & Burn $^{f}$ & 15.6 & 7.8 & 7.8 & 7.8 & 7.8 & 3.9 & 160 \\
\hline Sau G 16 & Burn $^{f}$ & 15.6 & 7.8 & 7.8 & 62.5 & 15.6 & 3.9 & 160 \\
\hline Sau G $18^{\mathrm{b}, \mathrm{c}}$ & Burn $^{f}$ & 7.8 & 3.9 & 7.8 & 7.8 & 7.8 & 7.8 & 80 \\
\hline Sau G $19^{b, c}$ & Burn $^{f}$ & 7.8 & 7.8 & 3.9 & 15.6 & 7.8 & 3.9 & 40 \\
\hline Sau G $7^{\mathrm{a}, \mathrm{c}}$ & Vaginal Swab ${ }^{\mathrm{f}}$ & 15.6 & 7.8 & 7.8 & 3.9 & 15.6 & 7.8 & 160 \\
\hline Sau G 13 & Vaginal Swab & 15.6 & 7.8 & 7.8 & 15.6 & 15.6 & 3.9 & 160 \\
\hline Sau G 6 & Blood $^{\mathrm{f}}$ & 7.8 & 7.8 & 7.8 & 15.6 & 15.6 & 15.6 & 160 \\
\hline Sau G $12^{b, c}$ & Blood $^{\mathrm{f}}$ & 31.2 & 7.8 & 15.6 & 31.2 & 7.8 & 15.6 & 80 \\
\hline Sau G $14^{c}$ & Wound Swabs ${ }^{\mathrm{f}}$ & 31.2 & 7.8 & 3.9 & 31.2 & 7.8 & 7.8 & 40 \\
\hline Sau G $8^{c}$ & Ear Swab ${ }^{f}$ & 15.6 & 7.8 & 7.8 & 31.2 & 31.2 & 7.8 & 80 \\
\hline Sau G $22^{d}$ & Eye $S w a b^{f}$ & 15.6 & 3.9 & 7.8 & 15.6 & 7.8 & 7.8 & 40 \\
\hline Sau G $20^{\mathrm{b}}$ & Catheter Tip ${ }^{f}$ & 7.8 & 3.9 & 3.9 & 7.8 & 7.8 & 1.9 & 160 \\
\hline Sau MTB ${ }^{\mathrm{b}, \mathrm{c}}$ & Pathogen ${ }^{g}$ & 7.8 & 7.8 & 7.8 & 31.2 & 7.8 & 7.8 & 160 \\
\hline Sau NCTC $6571^{\mathrm{e}}$ & Reference Strain ${ }^{\mathrm{h}}$ & 15.6 & 3.9 & 7.8 & 15.6 & 31.2 & 3.9 & 160 \\
\hline Sau MTCC $737^{\mathrm{e}}$ & Reference Strain & 7.8 & 7.8 & 7.8 & 31.2 & 15.6 & 3.9 & 160 \\
\hline
\end{tabular}

aVISA = vancomycin intermediate $S$. Aureus; ${ }^{\mathrm{b} M R S A}=$ methicillin resistant $S$. aureus; ${ }^{\mathrm{c} M A R S A}$ : Multi- antibiotic resistant $S$. aureus; ${ }^{\mathrm{d} V R S A}=$ vancomycin resistant S. aureus; ${ }^{\mathrm{e}} \mathrm{ASTS}=$ antibiotic susceptibility testing strain. ${ }^{\mathrm{f}} \mathrm{GMCP}=$ Govt. Medical College, Patiala, Punjab, India; ${ }^{\mathrm{g}} \mathrm{MTB}=\mathrm{Microbiology} \&$ Tumor Biology Centre, Karolinska Institute, Stockholm, Sweden; ' $L H M C$ = Lady Harding Medical College, New Delhi, India; NCTC, UKNCC: National Collection of Type Cultures, U.K.; 'MTCC, IMTECH: Microbial Type Culture Collection, Institute of Microbial Technology, Chandigarh, India.

less potent compound $\mathbf{2} \mathbf{c}$ that has only one nitro group at 2-position of ring $\mathrm{A}$, displaying MIC values in the range of 3.9-7.8 $\mu \mathrm{g} \mathrm{mL} \mathrm{m}^{-1}$. A common feature of both these compounds, as mentioned above, is the presence of hydroxyl group at 2-position of ring B.

Compounds $\mathbf{1 d}$ and $\mathbf{2 f}$ were not as potent as compounds $\mathbf{2 b}$ and $\mathbf{2 c}$, as discussed above. In both these compounds, the nitro group of ring $\mathrm{A}$ at 2 and 4 positions has been replaced by chloro group and the hydroxy group at 2-position of ring $\mathrm{B}$ has been replaced by nitro (1d) and amino (2f) groups, respectively. Compound 1d with the nitro group was the better of the two, showing MIC of 3.9-7.8 $\mu \mathrm{g} \mathrm{mL}^{-1}$ against eleven resistant strains and 15.6-31.2 $\mu \mathrm{g} \mathrm{mL}^{-1}$ against the remaining strains. However, compound $2 \mathbf{f}$ with amino group at same position showed MIC range of 3.9-7.8 $\mu \mathrm{g} \mathrm{mL}^{-1}$ against five resistant strains only. MIC value of $\mathbf{2 f}$ extended from 15.6-31.2 $\mu \mathrm{g} \mathrm{mL}-1$ for rest of the fifteen strains. Compounds $\mathbf{1 d}$ and $\mathbf{2 f}$ again corroborated with our previous studies (Table 1), confirming that the presence of an amino group at 2-position of ring B reduces its potential as an antibacterial agent.

Compound $\mathbf{3 f 3}$ with a chloro amide group at 2-position of ring B displayed an MIC range of 7.8-15.6 $\mu \mathrm{g} \mathrm{mL}^{-1}$ against nineteen strains confirming good antibacterial potential. Table 3 summarizes antibacterial activity against different resistant strains. It is clear from the table that the most potent compound to least potent compounds can be written in the order, $\mathbf{2} \mathbf{b}>\mathbf{2 c}>\mathbf{1 d}>$ $\mathbf{3 f 3}>\mathbf{2 f}$. Thus, antibacterial response of the compounds was comparable to that of triclosan, but greatly improved than the other control, cefepime, having MIC in the range $40-160 \mu \mathrm{g} \mathrm{mL} \mathrm{m}^{-1}$. 
Table 3. Summary of antibacterial activity for the compounds against resistant strains

\begin{tabular}{lcccccccc}
\hline & & \multicolumn{7}{c}{ MIC range of test compounds and control / $\left(\mu \mathrm{g} \mathrm{mL}^{-1}\right)$} \\
\cline { 3 - 9 } Culture source & No. of isolates & $\mathbf{1 d}$ & $\mathbf{2 b}$ & $\mathbf{2 c}$ & $\mathbf{2 f}$ & $\mathbf{3 f 3}$ & $\begin{array}{c}\text { Triclosan } \\
(\mathrm{control})\end{array}$ & $\begin{array}{c}\text { Cefepime } \\
(\mathrm{control})\end{array}$ \\
\hline Pus & 04 & $3.9-15.6$ & $3.9-7.8$ & $3.9-15.6$ & $15.6-31.2$ & 15.6 & $3.9-7.8$ & 160 \\
Burn & 04 & $7.8-15.6$ & $3.9-7.8$ & $3.9-7.8$ & $7.8-62.5$ & $7.8-15.6$ & $3.9-7.8$ & $40-160$ \\
Urine & 03 & $3.9-7.8$ & $3.9-7.8$ & $7.8-15.6$ & $7.8-31.2$ & $7.8-15.6$ & 7.8 & 160 \\
Blood & 02 & $7.8-31.2$ & 7.8 & $7.8-15.6$ & $15.6-31.2$ & 15.6 & 15.6 & $80-160$ \\
Vaginal swabs & 02 & 15.6 & 7.8 & 7.8 & $3.9-15.6$ & 15.6 & $3.9-7.8$ & 160 \\
Ear swab & 01 & 15.6 & 7.8 & 7.8 & 31.2 & 31.2 & 7.8 & 80 \\
Wound swab & 01 & 31.2 & 7.8 & 3.9 & 31.2 & 7.8 & 7.8 & 40 \\
Catheter tip & 01 & 7.8 & 3.9 & 3.9 & 7.8 & 7.8 & 1.9 & 160 \\
Eye swab & 01 & 15.6 & 3.9 & 7.8 & 15.6 & 7.8 & 7.8 & 40 \\
Reference & 02 & $7.8-15.6$ & $3.9-7.8$ & 7.8 & $15.6-31.2$ & $15.6-31.2$ & 3.9 & 160 \\
\hline
\end{tabular}

\section{Conclusions}

In conclusion, diphenyl amines were synthesized and characterized by NMR and mass spectrometry studies. All synthesized compounds were tested for their in vitro antibacterial activity against eight Gram-positive and Gram-negative strains in the prelimanry studies. Most of the compounds showed inhibitory activity against S. aureus. Potent compounds from preliminary studies were evaluated against resistant strains of $S$. aureus. From the results obtained above for Gram-positive, Gram-negative and resistant $S$. aureus strains it can be concluded that hydroxyl group at 2-position of ring B potentiates the antibacterial activity and overcomes the antibiotic resistance. The chloro groups at positions 2 and 4 of ring $\mathrm{A}$ and nitro at 2 position of ring $\mathrm{B}$ also show good antibacterial results against all the stains. However, if nitro group is replaced by amino in the compound it results in decrease of inhibitory activity. Modification of amino to corresponding chloro amide shows promise only for resistant $S$. aureus strains.

\section{Supplementary Information}

Supplementary data are available free of charge at http://jbcs.sbq.org.br as PDF file.

\section{Acknowledgments}

Authors MC and RKM are thankful to University Grants Commission (UGC), New Delhi, India, for the financial support (No. 41-293/2012) and senior research fellowship (SRF), respectively.

\section{References}

1. Head, M. G.; Fitchett, J. R.; Cooke, M. K.; Wurie, F. B.; Hayward, A. C.; Atun, R.; Lancet Infect. Dis. 2013, 13, 55.

2. David, M. Z.; Daum, R. S.; Clin. Microbiol. Rev. 2010, 23, 616.

3. Peacock, S. J.; Silva, I.; Lowy, F. D.; Trends Microbiol. 2001, 9, 605.

4. Korol, E.; Johnston, K.; Waser, N.; Sifakis, F.; Jafri, H. S.; Lo, M.; Kyaw, M. H.; PLoS One 2013, 8, e83743.

5. Barber, M.; J. Clin. Pathol. 1961, 14, 385.

6. Walsh, C.; Science 1999, 284, 442.

7. Sievert D. M.; Rudrik, J. T.; Patel, J. B.; McDonald, L. C.; Wilkins, M. J.; Hageman, J. C.; Clin. Infect. Dis. 2008, 46, 668.

8. Broder, S.; Venter, J. C.; Annu. Rev. Pharmacol. Toxicol. 2000, 40, 97.

9. Lu, H.; Tonge, P. J.; Acc. Chem. Res. 2008, 41. 11.

10. McMurry, L. M.; Oethinger, M.; Levy, S. B.; Nature. 1998, 394 , 531.

11. Silver, L. L.; Clin. Microbiol. Rev. 2011, 24, 71.

12. Freundlich, J. S.; Wang, F.; Tsai, H. C.; Kuo, M.; Shieh, H.M.; Anderson, J.W.; Nkrumah, L.J.; Valderramos, J. C.; Yu, M.; Kumar, T. R. S.; Valderramos, S. G.; Jacobs, W. R. Jr.; Schiehser, G. A.; Jacobus, D. P.; Fidock, D. A.; Sacchettini, J. C.; J. Biol. Chem. 2007, 282, 25436.

13. Chhibber, M.; Kumar, G.; Parasuraman, P.; Ramya, T. N. C.; Surolia, N.; Surolia, A.; Bioorg. Med. Chem. 2006, 14, 8086.

14. Bahadur, S.; Singh, S. P.; Verma, H. N.; Awasthi, L. P.; Biol. Plant. 1980, 22, 241.

15. Ferreira, I. C. F. R.; Calhelha, R. C.; Estevinho, L. M.; Queiroz, M. J. R. P.; Bioorg. Med. Chem. Lett. 2004, 14, 5831.

16. Pinto, E.; Queiroz, M. J. R. P.; Vale-saliva, L. A.; Oliveira, J. F.; Begouin, A.; Begouin, J. M.; Krisch, G.; Bioorg. Med. Chem. 2008, 16, 8172 . 
17. Clinical and Laboratory Standards Institute (CLSI): Performance Standards for Antimicrobial Disc Susceptibility tests, NCCLS M100- S12, Wayne, 2002.

18. Gomber, C.; Saxena, S.; Cent. Eur. J. Med. 2007, 2, 79.

19. Zhang, H.; Cai, Q.; Ma, D.; J. Org. Chem. 2005, 70, 5164.

20. Gulevskaya, A. V.; Tyaglivaya, I. N.; Verbeeck, S.; Maes, B. U. W.; Tkachuk, A. V.; ARKIVOC 2011, IX, 238.

21. Chauhan, S. M. S.; Singh, R.; Geetanjali; Synth. Commun. 2003, 33, 2899.

22. Zhu, Y.; Lin, G.; Chen, Y.; Synthesis 1990, 5, 430.

23. Skarzewski, J.; Skrowaczewska, Z.; Tetrahedron 1976, 32, 1221.
24. Dubowchik, G. M.; Han, X.; Vrudhula, V. M.; Zuev, D.; Dasgupta, B.; Michne, J. A.; US pat. WO2002058704 2002 (CA2434558A1).

25. Perozzo, R.; Kuo, M.; Sidhu, A. B. S.; Valiyaveettil, J. T.; Bittman, R.; Jacobs, Jr. W. R.; Fidock, D. A.; Sacchettini, J. C.; J .Biol. Chem. 2002, 277, 13106.

26. Sader, H. S.; Fritsche, T. R.; Kaniga, K.; Ge, Y.; Jones, R. N.; Antimicrob. Agents Chemother. 2005, 49, 3501.

Submitted: October 22, 2015

Published online: January 27, 2016 